\title{
Posterior cortical ribboning in the Heidenhain variant of Creutzfeldt-Jakob Disease
}

\author{
Hipersinal cortical posterior na variante Heidenhain da Doença de Creutzfeldt-Jakob \\ Camila Silva FREITAS', Marilia Gonçalves Maciel PINHEIRO', Eduardo Jorge da FONTE', \\ Adriano Nassri HAZIN', Jerusa SMID², Breno José Alencar Pires BARBOSA ${ }^{1,2}$
}

A 67-year old woman presented with visual disturbances followed by rapid cognitive decline in three months. She was disoriented on admission, with spatial hemineglect, oculomotor apraxia, and levitation of her left hand. She could not recognize numbers or letters during visual tests. Examination revealed prominent frontal reflexes, limb rigidity, and bilateral Babinski's sign. A brain MRI showed cortical DWI hyperintensities (Figure 1). EEG was positive for generalized complex periodic waves and CSF analysis revealed elevated 14-3-3 protein levels, leading to the diagnosis of probable Creutzfeldt-Jakob Disease (CJD). The Heidenhain variant of CJD is an atypical presentation with predominant visual disturbances followed by rapidly progressive dementia ${ }^{1,2}$.
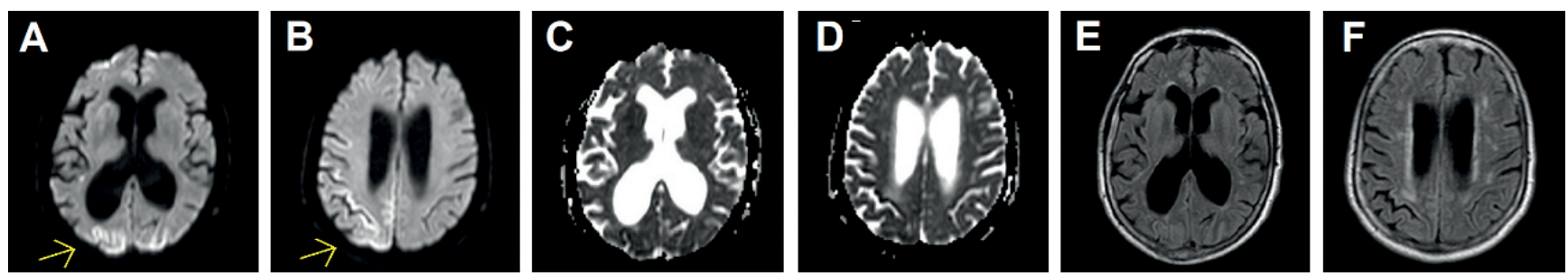

Figure 1. Diffusion-weighted images (DWI) revealing enlarged ventricles and asymmetric hyperintensities in a cortical ribboning pattern mostly in right occipital and parietal areas, suggesting restricted diffusion lesions (arrows, A and B). The same findings are seen to a lesser extent in the right putamen ( $\mathrm{A}$ and $\mathrm{C}$ ). C and D show corresponding apparent diffusion coefficient hypointensities in the same territory. There are no relevant findings in the Fluid Attenuation Inversion Recovery images (FLAIR, E and F), underscoring the relevance of DWI acquisition in such cases.

\section{References}

1. McGrath ER, Batra A, Lam AD, Rizzo JF, Cole AJ. Clinical Reasoning: A 64-year-old man with visual distortions. Neurology. 2016;87(21):e252-e256.3. https://doi.org/10.1212/ WNL.0000000000003357
2. Baiardi S, Capellari S, Ladogana A, Strumia S, Santangelo M, Pocchiari M, et al. Revisiting the Heidenhain Variant of Creutzfeldt-Jakob disease: evidence for prion type variability influencing clinical course and laboratory findings. J Alzheimers Dis JAD. 2016;50(2):465-76. https://doi.org/10.3233/JAD-150668

${ }^{1}$ Instituto de Medicina Integral Prof. Fernando Figueira, Recife PE, Brazil.

${ }^{2}$ Universidade de São Paulo, Faculdade de Medicina, Hospital das Clínicas, Grupo de Neurologia Cognitiva e do Comportamento, São Paulo SP, Brazil. Camila Silva FREITAS ID https://orcid.org/0000-0002-4511-0073; Marilia Gonçalves Maciel PINHEIRO; Eduardo Jorge da FONTE; Adriano Nassri HAZIN; Jerusa SMID; Breno José Alencar Pires BARBOSA iD https://orcid.org/0000-0003-4333-2024

Correspondence: Camila Silva Freitas; E-mail:camila@freitas.pe

Conflict of interest: There is no conflict of interest to declare.

Received on September 12, 2019; Received in its final form on October 15, 2019; Accepted on October $20,2019$. 